\title{
A distinct aspectual analysis of predicative possession in Brazilian Portuguese
}

\author{
Scott A. Schwenter \& Kendra V. Dickinson*
}

\begin{abstract}
We provide an aspectual analysis of Brazilian Portuguese predicative possessives, ter ('have') NP vs. estar com ('to be with') NP, which have been analyzed as denoting permanent versus temporary possession, respectively. Data include 20th century tokens of estar com NP $(n=553)$ and ter NP $(n=2976)$ from Davies' Corpus do Português. These data show that both possessive constructions can occur with the same temporal/aspectual reference and possessum, but that ter NP has a 0.55 typetoken ratio while estar com NP shows significantly lower $(\mathrm{p}<0.01)$ productivity (0.41). An online experimental survey in which we manipulated the possessum and the duration of the possession was designed and responded to by over 200 native Brazilian participants. Results show that while both forms are possible in all contexts they are nevertheless sensitive to the duration of the possession, thus suggesting that the association with permanent versus temporary possession is pragmatic in nature. We propose that estar com NP's possessive interval is co-extensive with the reference interval supplied by context, while ter NP's possessive interval is a superinterval of the reference interval, like progressive and imperfective aspects, respectively (Deo 2009).
\end{abstract}

Keywords. predicative possession; aspect; pragmatics; experimental methods; Brazilian Portuguese

1. Introduction. Many languages have more than one construction to express predicative (or verbal) possession; such languages are said to show a system of "split possession," and book-length studies have been devoted to the precise details of such "splits" across languages (e.g. Stolz, Kettler, Stroh, \& Urdze 2008). This research has identified three loci of these splits (Stolz et al 2008: 513), based on (1) empathy (possessor-oriented); (2) time/manner (possessive rela-tion-oriented); and (3) control (possessee-oriented). In this paper, we focus on the second of these split types, and in particular on a purported temporal distinction between "permanent" and "temporary" predicative possession.

More generally, Myler (2016) has pointed out that there are two separate, yet related, problems that need to be resolved across languages with respect to predicative possessive constructions. On the one hand, he notes that there exists the problem of "too many (surface) structures," i.e., different predicative possession constructions across languages, and even different constructions in the same language that overlap in meaning. On the other hand, there is the problem of "too many meanings" associated with a given predicative possessive construction, such as the have NP possessive in English, which can convey very different kinds of possession and ownership. One of the tasks of the analyst is to determine how it is possible for there to be so much variety in meaning associated with possessive constructions, and another, how it is

\footnotetext{
* A prior version of this paper was presented at a Hispanic Linguistics Colloquium at The Ohio State University. We thank the audience there and at the 2020 LSA for their questions and comments. For additional helpful feedback we thank Ashwini Deo, Natália Nunes, María Piñango, Malte Rosemeyer, our undergraduate RA Megan Kafka, and most especially Martín Fuchs and Mark Hoff, who made numerous comments to improve this version. We also thank all the Brazilian participants in our online survey. Authors: Scott A. Schwenter, The Ohio State University (schwenter.1@osu.edu) \& Kendra V. Dickinson, The Ohio State University (dickinson.130@osu.edu).
} 
possible for there to be so much variety in form to express similar, and sometimes even the same, meanings.

In this paper, we focus on the issue of multiple predicative possessive structures in one particular language, Brazilian Portuguese. We develop the idea that the distinction between permanent and temporary possession, while a basic intuition for differentiating competing constructions in split possession systems, is in fact an epiphenomenon of a more familiar aspectual distinction between imperfectivity and progressivity. This analysis allows us to account for the considerable overlap between the two constructions we examine from Brazilian Portuguese, as well as to explain the differing contextual sensitivity that these constructions display. We argue that the opposition between the two constructions is a privative one, inasmuch as the encoded semantics of one of the constructions (ter NP) lacks the specificity of its counterpart (estar com NP), which has a much more restricted distribution. We bring diverse types of evidence to bear on this argument, including qualitative contrasts, corpus data, and an original experimental survey in which we manipulated the degree of richness of the contextual information, as well as the possessum type, in order to test the choice process of native speakers when faced with the selection of one of the two constructions embedded in realistic discourse contexts.

2. Predicative possession in Brazilian Portuguese. The two constructions under analysis and which compete to convey predicative possession in Brazilian Portuguese (BP) are illustrated in (1) and (2) below.

(1) Ele tem cabelo loiro

He have.3SG.PRS hair blond

'He has blond hair.'

(2) Ele está com cabelo loiro

He be.3sG.PRS with hair blond

'He has blond hair.'

While both of these constructions would be translated into English via the have possessive construction, they are not necessarily interpreted in the same way. Without additional context, the version in (1) with the ter NP construction would be understood as conveying that the man in question is naturally blond, i.e. as inalienable possession. By contrast, the estar com NP version in (2) would normally be interpreted as conveying that the man dyed his hair blond from another color, i.e. the alienable interpretation.

Importantly, however, the version in (1) is also compatible with the alienable interpretation in an appropriate context. For instance, if we add a temporal adverbial to the sentence as in (1'), we can arrive at the same meaning as in (2):

$\begin{array}{lll}\text { (1') Ele tem } & \text { cabelo loiro esta semana } \\ \text { He have.3SG.PRS } & \text { hair } & \text { blond this week }\end{array}$

'He has blond hair this week.'

The addition of the temporal adverbial esta semana 'this week' cancels the inalienable interpretation that we get in (1) and conveys that the man in question has changed his hair color this week from another color the week before. In other words, the inalienable, or permanent, interpretation 
that is associated with (1) when it is presented in isolation is merely a Gricean (1975) conversational implicature that is defeasible given modified contextual information. ${ }^{1}$ For our purposes, this possibility of overlap between the ter NP and estar com NP constructions is crucial, since it suggests that the accepted semantic analysis of the former as conveying "permanent" aspect and the latter "temporary" aspect (Avelar 2009) is inaccurate. Rather, the distinction between the two constructions is a pragmatic one, and their association with permanence and/or temporariness is a probabilistic tendency.

Further evidence of the overlap comes from examples like (3a), where the ter NP construction can refer to possessive states with both permanent and temporary duration. This same example can be rendered with the ter NP construction in the first conjunct (permanent) and the estar com NP construction in the second (temporary), as in (3b). Not possible, however, is the case where the first conjunct occurs with estar com NP and the second with ter NP (3c), since the estar com NP construction cannot be used felicitously to denote inalienable possession, and the interpretation results in contradiction.

a. Ele tem cabelo loiro

He have.3SG.PRShair blond

mas esta semana tem

cabelo azul.

'He has blond hair but this week he has blue hair.'

(3) b. Ele tem

He have.3SG.PRS

cabelo loiro

mas esta semana está

hair blond

but this week

be.3SG.PRS

com

hair blue

azul

blue

'He has blond hair but this week he has blue hair.'

(3)

c. \#Ele está $\quad$ com
$\begin{aligned} & \text { He cabelo loiro mas esta semana tem } \\ & \text { cabelo azul. }\end{aligned}$ be.3SG.PRS with hair blond but this week have.3SG.PRS
hair blue
'He has blond hair but this week he has blue hair.' (Intended)

As far as we can tell, basic facts such as these about the distribution of the two predicative possession constructions in BP have not been brought to light before. Instead, at least since the classic work by Freeze (1992) on existentials and locatives (cf. also Clark 1978), the contrast between the two constructions has instead served as a test case for structural, as opposed to interpretational, differences (see Myler 2016 for a comprehensive discussion of the structural issues surrounding predicative possession).

Stolz et al. (2008) analyze the use of estar com NP in the European Portuguese translation of the fourth volume of the popular Harry Potter series. They find that the construction is employed for a range of uses for what they term "momentary" possession (2008: 433). Their table below shows the domains they identify for each of the two constructions.

\footnotetext{
${ }^{1}$ Perini (2002: 277) claims that the example Ele tem dor de cabeça 'He has a headache' to express a momentary state is "not common and sounds literary or old-fashioned" in present-day BP. As a result, the sentence "will normally be understood only as 'He is subject to headaches,' not as 'He has a headache (now)"' (ibid.). However, native speaker consultants report that the addition of a temporal adverb such as hoje 'today' would greatly improve the momentary state interpretation, and our survey results below corroborate this intuition.
} 


\begin{tabular}{lll} 
& ter NP & estar com NP \\
\hline Human & all & $?$ \\
Body part & inalienable & alienable, current position \\
Clothes & own & wear/carry \\
Objects & own & carry \\
Illnesses & permanent & momentary \\
Physico-mental states & permanent & momentary \\
Abstract concepts & permanent & momentary \\
\hline
\end{tabular}

Table 1. Domains of ter NP vs. estar com NP (adapted from Stolz et al. 2008: 433)

While we make no claims regarding the similarities or differences between BP and European Portuguese, the examples that they analyze from the Harry Potter volume appear to be possible uses in BP as well. However, it is notable that they do not analyze the uses of ter NP, but rather only assume its interpretation based on the examples of estar NP that are included in their analysis. This method is problematic since it ignores the overall distribution of the two constructions in the text. It also fails to notice that all of the examples of estar NP in the Harry Potter text included in the analysis could also be rendered by ter NP, modulo, in some cases, additional contextual information. Nevertheless, we took the Stolz et al. (2008) typology of domains in Table 1 as a basis for constructing our survey methodology, reported below, in order to test these authors' claims.

Avelar (2009a, 2009b) is the most complete existing description and analysis of the contrast between ter NP and estar com NP in BP. Although not concentrating on the meanings of the two constructions, he makes the claim that "the semantic difference between estar com and ter can be characterized in aspectual terms" (2009a: 141). He offers the minimal pair in (4) as evidence for this position:

(4) a. O Pedro está com dinheiro.

The Pedro be.3SG.PRS with money

'Pedro has money.'

(4) b. O Pedro tem dinheiro.

The Pedro have.3sG.PRS money

'Pedro has money.'

Avelar's explanation of the "semantic difference" between these two sentences is as follows: "in [4a] ... the relation between Pedro and money must be interpreted as a transitory or recently acquired possession, expressing the idea that Pedro has money now, at this moment. In [4b], by contrast, the relation between Pedro and money is normally taken as a more permanent or enduring possession. In other words, [4b] - but not [4a] - is easily interpreted as meaning that Pedro is rich." (2009a: 141; emphasis added). We have boldfaced several words in this quotation to highlight the possibility that both sentences, when embedded into a discourse context, can have rather distinct interpretations than those proposed by Avelar. For instance, (4a) can have an inchoative interpretation in which Pedro has just acquired money in some way; however, in this instance, there is no necessary implication that he will later not have any money. Indeed, this interpretation is fully compatible with a scenario in which Pedro has just inherited a fortune and will now 
be rich for the rest of his life, i.e. permanent possession. The phrases "normally taken" and "easily interpreted" in the explanation of the meaning of (4b) also suggest that other interpretations are possible. For instance, just adding the temporal adverb agora 'now' to ( $4 \mathrm{~b}$ ) would lead to an inchoative, change-of-state interpretation just like the one that is given as a possible meaning for (4a). In addition, adding the temporal adverb hoje 'today' to (4b), in a context in which the interlocutors mutually know that Pedro has a below-average salary, would lead to the interpretation that Pedro is not rich but rather in the uncommon position of having money that particular day. The upshot of this discussion of the examples in (4) is that their difference is not semantic, but rather one that is pragmatic in nature, and their interpretations can be readily modified depending on the contextual circumstances in which these sentences are embedded.

Following standard Gricean (1975) pragmatic methodology, we can use cancelability (defeasibility) tests to show that there is no contradiction between the use of ter NP and a nonpermanent possessive interpretation; therefore, the "permanence" reading is a conversational implicature: $O$ Pedro tem dinheiro, mas amanhã terá gastado tudo 'Pedro has money, but by tomorrow he will have spent all of it'. Likewise, the temporary nature of possession with estar com NP is compatible with a more permanent state being true, as in O Pedro está com dinheiro, porque ele é um homem rico 'Pedro has money, because he is a rich man.' The relevant difference with the latter construction is that it is not possible to deny that Pedro has money somehow accessible to him at utterance time; it is entailed that he has immediate or at least easy access to the money. This is not a necessary interpretation with ter NP, but it is also not impossible, as long as either the discourse context or adverbial modification entails that Pedro has the money with or accessible to him at the moment. These cancelation facts strengthen the argument that the aspectual difference between the two constructions is pragmatic, not semantic, in nature.

Another piece of evidence for the overlap between the two constructions comes from the fact that contextual neutralization (Sankoff 1988: 153) between the two possessive constructions can be easily found in naturally-occurring examples, such as the following near-minimal pairs from BP speakers posting on Twitter:

(5) a. Sempre tenho saudades de você meu amor, como Always have.1SG.PRS longing of you my love how pode?

able.3SG.PRS

'I always have longing for you, my love, how is that possible?'

(5) b. Também te amo, sempre estou com saudades de você Also you love.1SG.PRS always be.1SG.PRS with longing of you 'I also love you, I always have longing for you'

(6) a. Agora tenho fome mas nenhuma comida que eu

Now have.1SG.PRS hunger but no food that I queira comer want.1SG.PRS.SUBJ eat:INF 'Now I'm hungry but [there's] no food that I want to eat'

(6) b. Estou me sentindo melhor mas agora estou com fome Be.1SG.PRS me feel.PRSPRT better but now be.1SG.PRS with hunger 'I'm feeling better but now I'm hungry' 
As these tweets illustrate, both possessive constructions can be used to express the same meanings, with a quantificational adverb like sempre 'always' or the temporal change-of-state adverb agora 'now'. While it is undeniable that there are usage preferences with respect to the two constructions, as we will show in more detail below, the point of interest here is that their usagepattern differences can be neutralized in discourse as in (5) and (6). Thus, any account of the meanings of these constructions will have to include an explanation for why such overlap is possible.

Despite the possibility of contextual neutralization and role of pragmatic meaning in the interpretation of these possessive constructions, we still find that the two constructions occur with distinct, albeit overlapping, distributions in corpus data. Using $20^{\text {th }}$ century data collected from Mark Davies' (2015-) Corpus do Português (over 1 billion words; accessible at www.corpusdoportugues.com), we examined tokens of the estar com NP $(\mathrm{n}=553)$ and ter NP $(\mathrm{n}=2976)$ constructions. Of the top 50 possessums with each construction, $40 \%(n=20)$ occurred with both estar com NP and ter NP. This is difficult to reconcile in a non-overlapping analysis of the two constructions as permanent vs. temporary. These possessums included temporary states like fome 'hunger' or febre 'fever,' protoypical stage-level predicates (Kratzer 1995) that on the existing aspectual analyses (e.g. Avelar 2009a, 2009b; Stolz et al. 2008) would not be predicted to occur with the purported permanent ter NP possessive construction (which ought to occur solely with individual-level predicates). The corpus data show moreover that the overall productivity of the two constructions is highly asymmetrical: ter NP had a type-token ratio of 0.55 (1632/2976), but estar com NP showed significantly lower productivity $(0.41,229 / 553)$ by a Pearson's chi-squared test $(\mathrm{p}<0.01)$. This result aligns with the cross-linguistic trend towards the generalized use of "have" constructions for predicative possession (Stassen 2009, 2013), as well as the use of alternative possessive constructions in more restricted contexts (Myler 2016).

On the basis of these facts, we argue for an aspectual analysis of the distribution of these possessive constructions that is distinct from previous explanations which have described their difference as a question of (non-)permanence. Instead, we propose that estar com NP's possessive interval is co-extensive with the reference interval supplied by context, while ter NP's possessive interval is a superinterval of the reference interval, similar to progressive and imperfective aspectual meanings, respectively (Deo 2009). We envision the relationship between the two forms in the following way, where the uses of estar com NP in the smaller oval are a proper subset of those of ter NP, whose much wider distribution is reflected by the larger oval.

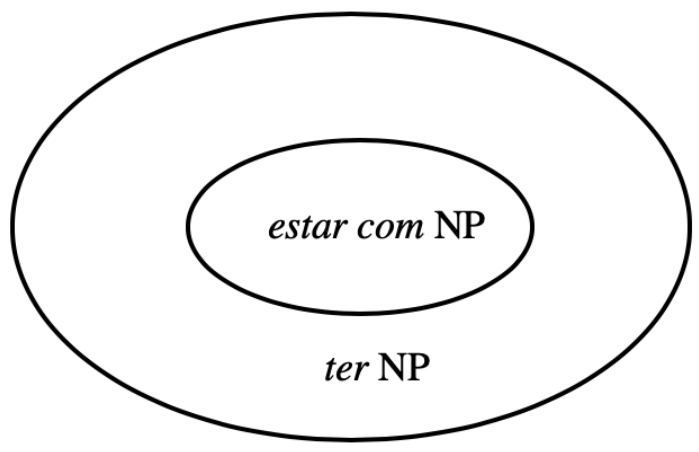

Figure 1. Proposed relationship between estar com NP and ter NP possessive constructions 
Recent research on imperfective and progressive aspect by Fuchs, Piñango, \& Deo (2019) and Fuchs and Piñango (2019) presents a case of overlapping distribution between constructions that resembles greatly the predicative possessives in BP. Fuchs et al. examine the overlap between the Spanish simple present (an imperfective aspectual marker) and the present progressive (progressive aspect). They are interested in the overlap in meaning between these two markers: while the simple present is typically used for generic states and habitual events, it can be interpreted in similar fashion to the present progressive (describing an ongoing action or event) given appropriate contextual support.

Fuchs et al. (2019) obtained acceptability ratings of the progressive interpretation of the two forms in what they called rich versus poor contexts, where rich contexts provide contextual support for the ongoing nature of the action due to the interlocutors' shared perceptual access, while the poor context does not provide such access. Here are two of their examples, translated from the Spanish originals:

Rich context:

Anna comes home from work, and goes to her son's room to look for him. She knocks on the door, opens it, and sees him sitting at his desk. Before she can say anything, he says to her:

-Estoy haciendo la tarea 'I'm doing my homework' (present progressive)

-Hago la tarea 'I do my homework' (simple present)

Poor context:

Anna comes home from work, and goes to her son's room to look for him. She knocks on the door, but her son does not answer. Before she gets to open the door, her son tells her:

-Estoy haciendo la tarea 'I'm doing my homework' (present progressive)

-Hago la tarea 'I do my homework' (simple present)

Respondents only saw one of the two response options (present progressive vs. simple present) and provided an acceptability rating. Fuchs et al.'s results showed that the Spanish simple present is significantly more acceptable with the progressive interpretation when it is contextually supported by the rich context. In the poor contexts, its acceptability ratings were very low by comparison. On the other hand, for the present progressive there was no difference in rich vs. poor contexts, because this marker does not depend on contextual support for its interpretation in contexts of ongoing situations, i.e. the construction's encoded semantic content conveys the intended progressive meaning in such contexts. These experimental results support the semantic/pragmatic analysis of imperfectives and progressives by Deo $(2009,2015)$ : the temporal interval to which imperfectives refer includes that of progressives (superordinate $>$ subordinate).

We hypothesize that ter NP will be chosen significantly more by BP speakers when it occurs in a rich context clarifying the duration of the possession, even when occurring with "temporary" (i.e. stage-level) possessums. The converse however will not be true given the relationship envi-sioned in Figure 1 between the two possessive constructions: estar com NP will not be chosen more when occurring in a rich context clarifying the permanent nature of the possession. Given that we use a forced-choice task, we expect the relative frequency of this construction to be 
lower in rich contexts, since it encodes temporariness and/or change of state. In addition, as Figure 1 above suggests, we hold that there is a one-way entailment relationship between estar com NP and ter NP. The estar com NP construction entails the ter NP, but ter NP does not entail estar com NP. In addition, whereas ter NP can be taken as referring to a super-interval of the reference interval, extending beyond it in both directions, estar com NP can be considered to be co-extensive with the reference interval, as reflected in Figure 2 (Deo 2009).

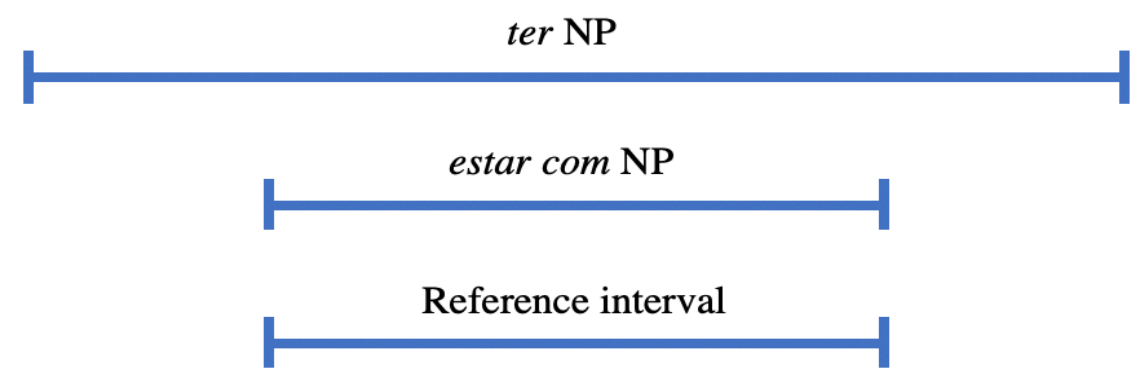

Figure 2. Temporal extension of ter NP and estar com NP

This entailment relationship between the two constructions can be demonstrated by the examples in (8) and (9) below. In (8a), where the assertion is made, using ter NP, that the speaker has their passport, this assertion can be modified in $(8 \mathrm{~b})$ to state that they have a passport, but they left it at home. However, in (9a) we see that where the same assertion can be made with the estar com NP construction, it cannot be modified to mean that the speaker has left their passport at home as in (9b). In (9a), the speaker obligatorily has their passport with them at the time of speech. The contrast between (8c) and (9c) also show that while it is possible to use ter NP and then estar com NP to deny current physical possession of one's passport, the converse is not possible, insofar as estar com NP entails that same current physical possession, and therefore cannot be canceled with ter NP (or, for that matter, with estar com NP in the second conjunct).

(8) a. Tenho meu passaporte.

have.1SG.PRS my.M passport.

'I have my passport.'

b. Tenho meu passporte, mas deixei em casa.

have.1SG.PRS my.M passport but leave.1SG.PST in house.

'I have my passport, but I left it at home.'

$\begin{array}{llllll}\text { c. Tenho } & \text { meu } & \text { passaporte, } & \text { mas não estou } & \text { com ele. } \\ \text { have.1SG.PRS } & \text { my.M } & \text { passport } & \text { but not be.1SG.PRS } & \text { with it }\end{array}$ 'I have my passport, but I don't have it with me.'

(9) a. Estou com meu passaporte.

be.1SG.PRS with my.M passport.

'I have my passport.'

b. \#Estou com meu passaporte, mas deixei em casa. be.1SG.PRS with my.M passport but leave.1SG.PST in house. I have my passport but I left it at home.' (Intended) 

c. \#Estou com
be.1SG.PRS with
'I have my passport but I don't have it with me.' (Intended)
ele.
it

These examples show that whereas estar com NP obligatorily includes only the reference interval, the ter NP construction can be used to make reference to a greater interval in which the possession is not necessarily actively ongoing or is inaccessible to the agent at utterance time.

\section{Survey}

3.1. SURVEY METHODOLOGY. To test our hypotheses, we created a force-choice task hosted on Qualtrics. We created a total of 52 target items, which consisted of a brief prompt for survey respondents to read, followed by two sentences for them to select between, which were syntactic minimal pairs varying only in the possessive construction (ter vs. estar com). Survey items were designed to vary with regard to contextual immediacy ( $+/$ - durative), temporal adverb (presence vs. absence), adverb type (extending vs. limiting) and possessum types (illnesses, physico-mental states, objects, abstract concepts).

Then, we created 8 different versions of the survey using a Latin Square design to ensure that each participant saw an equal number of $+/$ - durative contexts, an equal number of items with and without a temporal adverb, an equal number of possessum types, and saw each introductory prompt a maximum of one time. The items below show examples of non-durative (10a) vs. durative (10b) contexts.

(10) a. Brazilian Portuguese

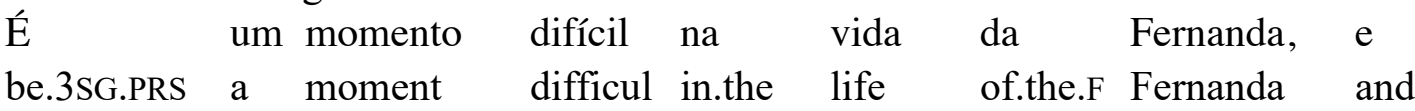

$\begin{array}{llllll}\text { ela } & \text { quer } & \text { explicar } & \text { para } & \text { a } & \text { amiga dela. } \\ \text { 3SG.SBJ.F } & \text { want.3SG.PRS } & \text { explain.INF } & \text { for } & \text { the.F } & \text { friend.F of.her }\end{array}$

'It is a difficult moment in Fernanda's life, and she wants to explain it to her friend'

(10) b. Brazilian Portuguese

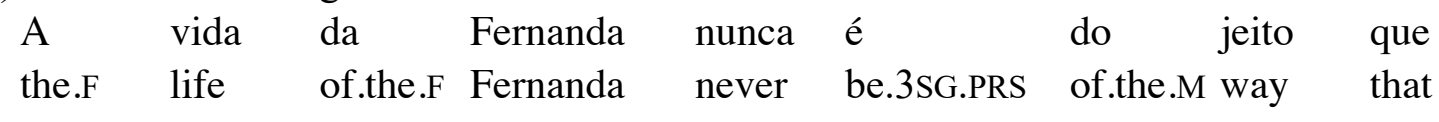

ela quer e ela sofre muitas dificuldades.
3SG.SBJ.F want.3SG.PRS and 3SG.SBJ.F suffer.3SG.PRS many.F difficulties. 'Fernanda's life never goes the way that she wants and she suffers many difficulties.'

As can be noted in the items above, (10a) sets up a scenario that is occurring in the present, with no mention of the difficult moment extending into the past or future, whereas (10b) sets up a context in which the difficulties in Fernanda's life are occurring over a long-term, extended period of time. After reading either (10a) or (10b), respondents were presented with two options, and asked to decide which option they thought Fernanda should say given the contextual set-up. The items below show the options presented to respondents without the additional presence of a temporal adverb (11a-b), and with an extending temporal adverb (12a-b), in this case the 
quantificational adverb sempre 'always.' The other temporal adverbs included in the survey were hoje 'today', ainda 'still', já 'already', todo dia 'every day', and ultimamente 'recently'.

(11) a. Brazilian Portuguese

Estou com problemas.

be.1SG.PRS with problems

'I have problems.'

(11) b. Brazilian Portuguese

Tenho problemas.

have.1SG.PRS problems

'I have problems.'

(12) a. Brazilian Portuguese

Sempre estou com problemas.

always be.1SG.PRS with problems

'I always have problems.'

(12) b. Brazilian Portuguese

Sempre tenho problemas.

always have.1SG.PRS problems

'I always have problems.'

Upon beginning the survey, respondents were advised that they would be presented with a number of different scenarios, and then be asked to select one of two options indicating which sentence they believed best described the scenario. Respondents were reminded that we were interested in their personal opinions, that there were no correct answers, and were informed of their rights as participants. Upon consenting to participate, respondents were randomly assigned a version of the instrument. Additionally, individual survey items and response options were randomized for each respondent.

\subsection{SURVEY PARTICIPANTS AND RESULTS. A total of 216 native speakers of Brazilian Portuguese} completed the survey. Ages ranged from 18-69 years old (mean =36.7, $\mathrm{sd}=11.5)$, and included 161 females, 51 males, and 4 who did not identify with either gender. Respondents were from all over Brazil, including the states of Belém, Ceará, Goiás, Mato Grosso, Minas Gerais, Pará, Paraíba, Paraná, Rio de Janeiro, Rio Grande do Sul, Rondônia, São Paulo, and Santa Catarina.

Our data $(\mathrm{N}=1377)^{2}$ show that both ter NP and estar com NP were variably chosen in all conditions and with all possessums, revealing no categorial usage of either construction. The possessums that came closest to promoting near-categorical selection of a particular construction were oportunidades ('opportunities'), which was selected with ter NP $85.8 \%$ of the time, and fome ('hunger') which was selected with estar com NP $93.8 \%$ of the time.

\footnotetext{
${ }^{2}$ The total number of data points is not divisible by the total number of respondents $(\mathrm{N}=216)$ because we allowed for respondents who had skipped a single question to be included for analysis.
} 
In general, the data show a greater preference for the estar com NP construction with illnesses and physico-mental states, as opposed to physical objects and abstract concepts; see Figure 3, visualized using ggplot2 (Wickham 2009). Furthermore, a Pearson's chi-squared test reveals that there is no significant different between illness and physico-mental states with regard to respondent preference for either of the possessive constructions $\left(X^{2}=0.65917, p=0.4169\right)$. Likewise, while objects and abstract concepts showed a slight preference for the estar com NP construction, respondents selected the ter NP construction far more often with these possessum types. A Pearson's chi-squared test reveals that there is no significant difference between objects and abstract concepts with regard to respondent preference for either of the possessive constructions $\left(\mathrm{X}^{2}=0.10073, \mathrm{p}=0.751\right)$. However, a comparison between illnesses and physico-mental states, on the one hand, vs. objects and abstract concepts, on the other, reveals that the two groups are significantly differenT from each other $\left(\mathrm{X}^{2}=46.633, \mathrm{p}<.001\right)$, with the former showing a greater preference for the estar com NP construction than the latter.

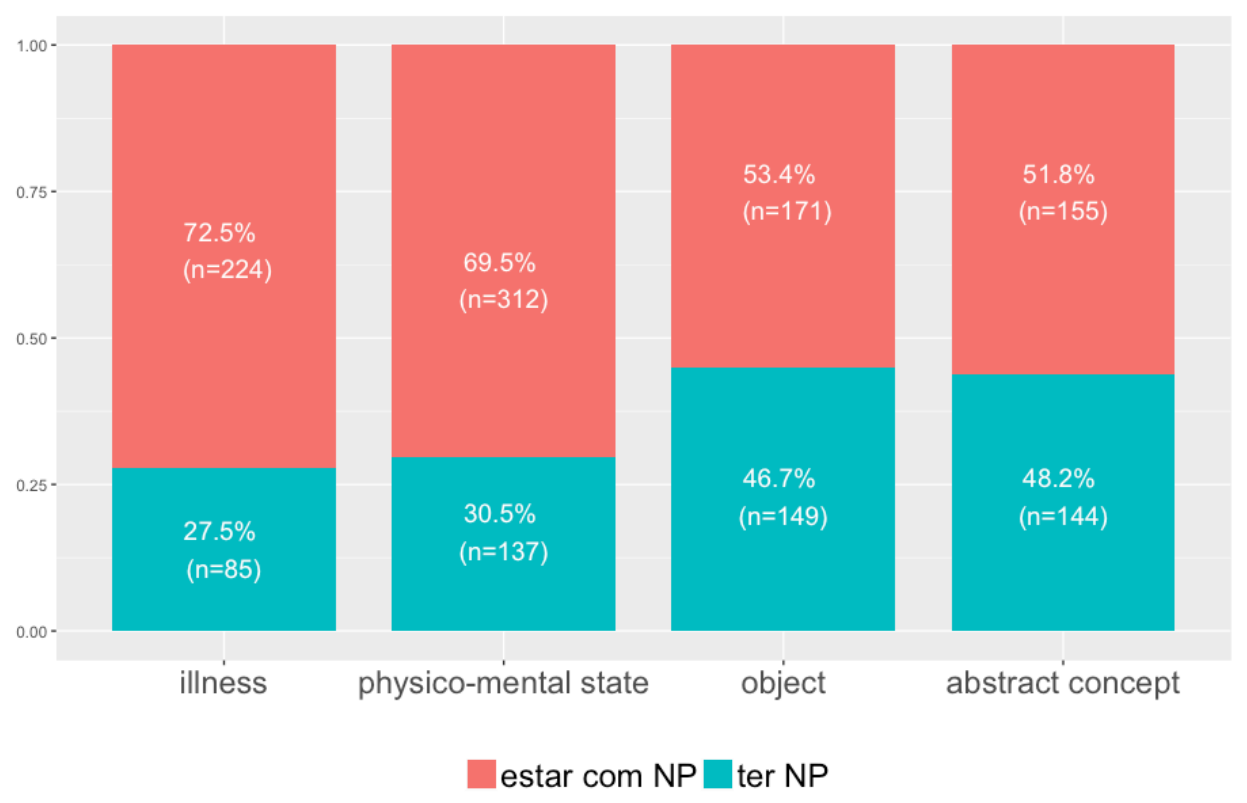

Figure 3. Distribution of possessive constructions by possessum types

In addition to a preference for estar com NP overall and with illnesses and physico-mental states, the data also show an effect of the temporal context on the selection of possessive construction. In the durative temporal contexts, estar com NP was selected $50.2 \%(\mathrm{n}=328)$ of the time, while in non-durative contexts it was selected $73.9 \%(n=535)$ of the time. Figure 4 below illustrates these differences. 


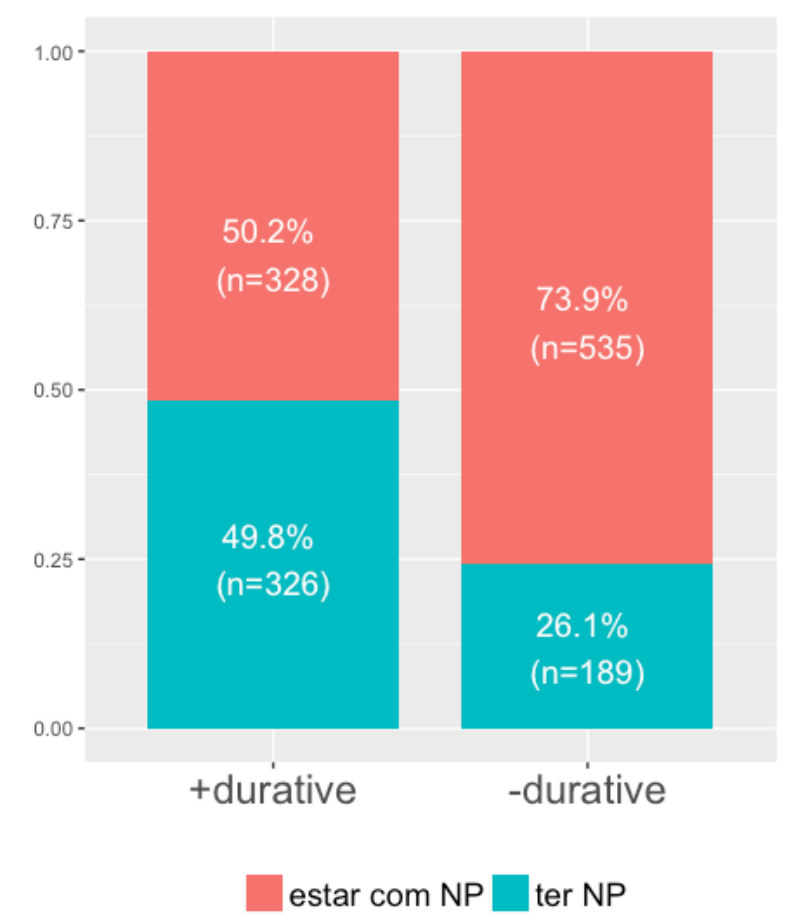

Figure 4. Distribution of possessive constructions by context type

3.3. Statistical methodology. Data were examined and analyzed in R (R Core Team 2017) using the lme4 package (Bates, Maechler, Bolker, \& Walker 2015). We used a step-up method to build explanatory models of the data and then compared them using the ANOVA function in $\mathrm{R}$ to determine the best-fit model for the data. The predictor variables included in the analysis were Context (+/- durative), Adverb (presence vs. absence), and Adverb type (limiting vs. extending vs. none). Though we demonstrated above that possessum plays a role in the selection of possessive construction, we included possessum as a random intercept in our statistical models for several reasons.

First, the possessums that we selected do not exhaust the possibilities for each possessum type, and, despite our efforts to choose suitable exemplars, there is no way to ensure that they are fully representative of each type. Furthermore, in the case of our survey, each possessum had a different context and carrier sentence, due to their differences in meaning. Therefore, we cannot effectively disentangle each possessum from its context, and as a result we include possessum as a random intercept. In addition, following standard practice, we include respondent as a random intercept to account for repeated measures. ${ }^{3}$

3.4. Statistical analysis. The best fit model for the data includes both context (+/- durative) and adverb type (extending vs. limiting). The model also includes respondent and possessum as random intercepts, as explained above. The output of this model is shown in Table 2 below, and shows the probability of selection of the ter construction over the estar com construction.

\footnotetext{
${ }^{3}$ Models including random slopes failed to converge.
} 


\begin{tabular}{llcccc} 
& & estimate & std. error & $z$-value & $p$-value \\
\hline & intercept & -0.10417 & 0.37283 & -0.279 & 0.7799 \\
$\begin{array}{l}\text { Context } \\
\text { (ref. level =+durative) }\end{array}$ & -durative & -0.94563 & 0.17965 & -5.264 & $\begin{array}{c}1.41 \mathrm{e}-07 \\
* * *\end{array}$ \\
\hline $\begin{array}{l}\text { Adverb type } \\
\text { (ref. level = none) }\end{array}$ & limiting & 1.34580 & 0.61108 & 2.202 & $\begin{array}{c}0.0276 \\
*\end{array}$ \\
& extending & 0.09494 & 0.18081 & 0.525 & 0.5995 \\
& & & & & \\
& & & & & \\
\hline
\end{tabular}

variance std. deviation

$\begin{array}{llll} & \text { respondent } & 0.4807 & 0.6933 \\ \text { Random intercepts } & \text { possessum } & 1.4323 & 1.1968\end{array}$

\section{Table 2. Output of Mixed-Effects Logistic Regression}

The output of this model reveals that the ter NP construction is selected by respondents significantly less often in non-durative contexts than the estar com NP construction. Furthermore, the presence of a limiting adverb increases the likelihood of the selection of ter NP. Releveling of the factors from Adverb type showed that limiting and extending adverbs were also significantly different from each other. This shows that the presence of a limiting adverb significantly increases respondents' selection of the ter NP construction, whereas the presence of an extending adverb did not promote the use of ter NP over baseline. This reveals that, in the presence of significant contextual support, in this case, a temporally limiting adverb, ter NP becomes more compatible with a more immediate (or what has been called "temporary" in prior research) reading, in much the same way that a simple present form in Spanish becomes more compatible with an ongoing verbal situation with rich contextual support (Fuchs et al. 2019). What we might conclude from this result is that the default interpretation for ter NP is of a possessive situation that extends in time beyond the reference interval, much like an imperfective aspectual marker does; but when co-occurring in a context with a limiting adverb the interval of ter NP can be interpreted without contradiction as co-terminous with the reference interval, again illustrating that the meaning of "permanence" attributed to ter NP in prior research (Avelar 2009a, 2009b; Stolz et al. 2008) is actually a conversational implicature, not a semantic entailment. ${ }^{4}$

4. Conclusions. While "permanent" vs. "temporary" is an intuitive first description of most uses of ter NP vs. estar com NP in BP, it fails to explain the considerable interpretational overlap encountered between the two constructions, overlap that has been overlooked in prior research. As we have argued in this paper, the distinction between the two constructions is more pragmatic than semantic: the "permanence" of ter NP is a defeasible inference that is dependent on

\footnotetext{
${ }^{4}$ Martín Fuchs (p.c.) has suggested that another way to conceive of the difference between the BP possessives is as a Horn-scale (Horn 1984) of the form <estar com, ter>, where estar com NP unilaterally entails ter NP, and ter NP implicates that the speaker was not in a position to employ estar. In this way, ter NP would implicate that the possession lasted beyond the boundaries of the reference interval. We plan to explore this analysis in future work.
} 
contextual features and the interpretation of the possessum. The temporal interval to which ter NP refers always includes that of estar com NP (i.e. in a superordinate $>$ subordinate relationship; see Figure 1 above); herein lies the parallelism between these competing possessive forms and the more well-known aspectual distinction and competition between imperfectives and progressives (Deo 2009, 2015).

We situate this work alongside prior research on phenomena such as so-called "obligatory adjuncts" (Goldberg \& Ackerman 2001), on the distinction between stage-level and individuallevel predicates (Maienborn 2004, 2005; McNally 1994), and, of course, the Spanish imperfective domain (Fuchs et al. 2019; Fuchs \& Piñango 2019). These phenomena were long thought to have a semantic or grammatical basis but were later demonstrated to have contextually determined interpretations and distributions. Similar research should now be carried out on the meaning of split possession in other languages, especially those whose systems are purportedly based on a permanent vs. temporary aspectual difference such as in Moroccan Arabic (Avelar 2009a) or Turkish (Stolz et al. 2008), for more precise characterizations of these systems. Research on languages such as Spanish where estar con NP (estoy con hambre 'I'm hungry') is less grammaticalized than in BP but still possible in limited possessive contexts could also help to determine in greater detail the underlying basis for this particular split. We hypothesize that what Stolz et al. (2008) meant by temporal distinctions in their typological survey of split possessive systems will actually turn out to be a more widespread aspectual difference like the one we have described here for Brazilian Portuguese.

\section{References}

Avelar, Juanito. 2009a. The comitative-copular basis of possessive-existential constructions. In Jairo Nunes (ed.), Minimalist essays on Brazilian Portuguese syntax, 139-160. Amsterdam: John Benjamins. https://doi.org/10.1075/la.142.10ave.

Avelar, Juanito. 2009b. Ter, ser e estar: Dinâmicas morfossintáticas em portugues brasileiro. Campinas, Brazil: Editora RG.

Bates, Douglas, Martin Maechler, Ben Bolke, \& Steve Walker (2015). Fitting linear mixedeffects models using lme4. Journal of Statistical Software, 67(1).1-48. https://doi:10.18637/jss.v067.i01.

Clark, Eve V. 1978. Locationals: existential, locative and possessive constructions. In Joseph H. Greenberg (ed.), Universals of human language, volume 4: Syntax. 85-126. Stanford, CA: Stanford University Press.

Davies, Mark. 2015-. Corpus do Português. Online. https://corpusdoportugues.org.

Deo, Ashwini. 2009. Unifying the imperfective and the progressive: partitions as quantificational domains. Linguistics and Philosophy 32(5). 475-521. https://doi.org/10.1007/s10988-0109068-z.

Deo, Ashwini. 2015. The semantic and pragmatic underpinnings of grammaticalization paths: The progressive to imperfective shift. Semantics and Pragmatics 8(14). 1-52. https://dx.doi.org/10.3765/sp.8.14.

Freeze, Ray. 1992. Existentials and other locatives. Language 68(3). 553-595. https://doi.org/10.2307/415794.

Fuchs, Martín \& María Mercedes Piñango. 2019. Explaining the forces underpinning grammaticalization paths: The progressive-to-imperfective shift in three varieties of Spanish.

Proceedings of the Linguistic Society of America (PLSA) 4. 6:1-11. https://doi.org/10.3765/plsa.v4i1.4491. 
Fuchs, Martín, María Mercedes Piñango \& Ashwini Deo. 2019. Operationalizing the role of context in language variation: The role of perspective alignment in the Spanish imperfective domain. In Thomas Gamerschlag, Tobias Kalenscher, Sebastian Löbner, Markus Schrenk \& Henk Zeevat (eds.). Selected papers from CoSt16 (Language, Cognition, and Mind Series). Berlin: Springer.

Goldberg, Adele \& Farrell Ackerman. 2001. The pragmatics of obligatory adjuncts. Language 77(4). 798-814. https://doi.org/10.1353/lan.2001.0219.

Grice, H. Paul. 1975. Logic and conversation. In Peter Cole \& Jerry Morgan (eds.), Syntax and semantics 3: Speech acts. 41-58. New York: Academic Press.

Horn, Laurence R. 1984a. Toward a new taxonomy for pragmatic inference: Q-based and Rbased implicature. In Deborah Schiffrin (ed.), Meaning, form, and use in context. 11-42. Washington, DC: Georgetown University Press.

Kratzer, Angelika. 1995. Stage-level and individual-level predicates. In Gregory N. Carlson \& Francis Jeffry Pelletier (eds.), The generic book. 125-175. Chicago: University of Chicago Press.

Maienborn, Claudia. 2004. A pragmatic explanation of the stage level/individual level contrast in combination with locatives. In Brian Agbayani, Vida Samiian \& Benjamin Tucker (eds.), Proceedings of the Western Conference on Linguistics 15. 158-170.

Maienborn, Claudia. 2005. A discourse-based account of Spanish ser/estar. Linguistics 43(1). 155-80.

McNally, Louise. 1994. Adjunct predicates and the individual/stage distinction. In Erin Duncan, Donka Farkas \& Philip Spaelti (eds.), Proceedings of the 12th West Coast Conference on Formal Linguistics. 561-576. Stanford: CSLI.

Myler, Neil. 2016. Building and interpreting possession sentences. Cambridge, MA: MIT Press. https://doi.org/10.7551/mitpress/9780262034913.001.0001.

Perini, Mário A. 2002. Modern Portuguese: A reference grammar. New Haven: Yale University Press.

R Core Team. 2017. R: A language and environment for statistical computing. R Foundation for Statistical Computing,Vienna, Austria. https://www.R-project.org/.

Sankoff, David. 1988. Sociolinguistics and syntactic variation. In Frederick J. Newmeyer (ed.), Linguistics: the Cambridge survey, Vol. 4: The Socio-cultural context. 140-161. Cambridge: Cambridge University Press.

Stassen, Leon. 2009. Predicative possession. Amsterdam: John Benjamins.

Stassen, Leon. 2013. Predicative Possession. In Matthew S. Dryer \& Martin Haspelmath (eds.) The World Atlas of Language Structures Online. Leipzig: Max Planck Institute for Evolutionary Anthropology. (Available online at http://wals.info/chapter/117, Accessed on 202002-21.)

Stolz, Thomas, Sonja Kettler, Cornelia Stroh, \& Anna Urdze. 2008. Split possession. Amsterdam: John Benjamins. https://doi.org/10.1075/slcs.101.

Wickham, Hadley. 2009. ggplot2: Elegant graphics for data analysis. New York: Springer-Verlag. 